\title{
CDKN2A germline alterations and the relevance of genotype-phenotype associations in cancer predisposition
}

\author{
Sock Hoai Chan ${ }^{1}$, Jianbang Chiang ${ }^{1}$ and Joanne Ngeow ${ }^{1,2,3^{*}}$ (D)
}

\begin{abstract}
Although CDKN2A is well-known as a susceptibility gene for melanoma and pancreatic cancer, germline variants have also been anecdotally associated with a broader range of neoplasms including neural system tumors, head and neck squamous cell carcinomas, breast carcinomas, as well as sarcomas. The CDKN2A gene encodes for two distinct tumor suppressor proteins, p16 $6^{\mathrm{INK} 4 \mathrm{~A}}$ and $\mathrm{p} 14^{\mathrm{ARF}}$, however, the independent association of germline alterations affecting these two proteins with cancer is under-appreciated. Here, we reviewed CDKN2A germline alterations reported among individuals and families with cancer in the literature, specifically addressing the cancer phenotypes in relation to the molecular consequence on $\mathrm{p} 16^{\mathrm{INK} 4 \mathrm{~A}}$ and $\mathrm{p} 14^{\mathrm{ARF}}$. While melanoma is observed to associate with variants affecting both $\mathrm{p} 16^{\mathrm{INK} 4 \mathrm{~A}}$ and $\mathrm{p} 14^{\mathrm{ARF}}$ transcripts, it is noted that variants affecting $\mathrm{p} 14^{\mathrm{ARF}}$ are more frequently observed with a heterogenous range of cancers. Finally, we reflected on the implications of this inferred genotype-phenotype association in clinical practice and proposed that clinical management of CDKN2A germline variant carriers should involve dedicated cancer genetics services, with multidisciplinary input from various healthcare professionals.
\end{abstract}

Keywords: CDKN2A, Cancer predisposition, p16 $6^{\mathrm{INK} 4 \mathrm{~A}}, \mathrm{p} 14^{\mathrm{ARF}}$

\section{Background}

CDKN2A (cyclin dependent kinase inhibitor 2A, OMIM 600160 ) is a tumor suppressor gene that encodes for two proteins, namely $\mathrm{p} 16^{\mathrm{INK} 4 \mathrm{~A}}$ and $\mathrm{p} 14^{\mathrm{ARF}}$, critical for the regulation of cell cycle pathways. Genetic and epigenetic alterations inactivating $C D K N 2 A$ are frequently encountered in a myriad of cancers, with base sequence-altering events more common in cancer types such as melanoma, head and neck squamous cell carcinoma (HNSCC), pancreatic cancer, lung cancer, esophageal cancer, and glioblastoma multiforme (GBM) [1-3]. Germline alterations in CDKN2A are

\footnotetext{
* Correspondence: joanne.ngeow@ntu.edu.sg

${ }^{1}$ Cancer Genetics Service, Division of Medical Oncology, National Cancer Centre Singapore, Singapore 169610, Singapore

${ }^{2}$ Oncology Academic Clinical Program, Duke-NUS Medical School, Singapore 169857, Singapore

Full list of author information is available at the end of the article
}

most frequently associated with predisposition to melanoma and pancreatic cancer [4-8], detected through gene-panel testing in about $38 \%$ of melanoma-prone families $[6,9]$ but there have been sporadic reports implicating susceptibility to other neoplasms such as neural system tumors (NSTs), breast cancer, multiple myeloma, HNSCC, and sarcoma [10-18]. It is plausible that the varying cancer types reported with $C D K N 2 A$ genetic alterations can be distinguished by the different variant effects on $\mathrm{p} 16^{\mathrm{INK} 4 \mathrm{~A}}$ and $\mathrm{p} 14^{\mathrm{ARF}}$, although evidence to date are limited and conflicting $[12,13,16,19-21]$. Here, we reviewed the spectrum of CDKN2A germline variants and associated neoplasms reported in literature, focusing on the relationship between distinct variant consequences on $\mathrm{p} 16^{\mathrm{INK} 4 \mathrm{~A}} / \mathrm{p} 14^{\mathrm{ARF}}$ with the reported phenotypes. Variants evaluated include those detected in affected 
individuals through sequencing and/or classified as pathogenic or likely pathogenic in ClinVar database (version 2020-09-08, https://www.ncbi.nlm.nih.gov/ clinvar/) without conflicts in interpretation.

\section{$\mathrm{p} 16^{\mathrm{INK} 4 \mathrm{~A}} / \mathrm{p} 14^{\mathrm{ARF}}$ locus in the CDKN2A gene}

The CDKN2A gene spans $27.5 \mathrm{~kb}$ on chromosome $9 \mathrm{p} 21$ and is associated with over 10 transcript variants, of which the largest two encode for $\mathrm{p} 16^{\mathrm{INK} 4 \mathrm{~A}}$ and $\mathrm{p} 14^{\mathrm{ARF}}$ [22]. $\mathrm{p} 16^{\mathrm{INK} 4 \mathrm{~A}}$ is a 156 amino acid protein translated from a transcript of three exons (exons 1 1 $2,2,3$; RefSeq NM_000077), known to negatively regulate cell cycle progression through inhibition of cyclin-dependent kinases [23]. The largest transcript produces $\mathrm{p} 14^{\mathrm{ARF}}$ (RefSeq NM_058195), a 132 amino acid protein, encoded via an alternative open-reading frame and first exon (exon 1 $\beta$ ), with an established role of promoting p53 function through sequestration of MDM2 [24]. Consequently, $\mathrm{p} 16^{\mathrm{INK} 4 \mathrm{~A}}$ and $\mathrm{p} 14^{\mathrm{ARF}}$ are distinct proteins with different roles and no sequence homology, sharing only the use of same exons 2 and 3. Notably, although both tumor suppressors are encoded by three exons of similar size (exon $1 \alpha$ : $421 \mathrm{bp}$, exon 1ß: $486 \mathrm{bp}$, exon 2: $307 \mathrm{bp}$, exon 3: $490 \mathrm{bp}$ ), the bulk of translated sequence is localized to exon $1 \alpha / 1 \beta$ and exon 2 .

\section{Spectrum of $\mathrm{p} 16^{\mathrm{INK} 4 \mathrm{~A}} / \mathrm{p} 14^{\mathrm{ARF}}$ variants associated with neoplasms}

There are differences in molecular consequences of $C D K N 2 A$ variants reported in literature on $\mathrm{p} 16^{\mathrm{INK} 4 \mathrm{~A}}$ and $\mathrm{p} 14^{\mathrm{ARF}}$, which is expected given the use of different open-reading frames. Most of the $\mathrm{p} 16^{\mathrm{INK} 4 \mathrm{~A}}$-affecting variants are missense changes (28/55) followed by protein-disrupting variants (20/55, including truncating and null effects), occurring on exon $1 \alpha$ and exon 2 (Table 1). In comparison, almost one-third of these reported variants fall within intron 1 of $\mathrm{p} 14^{\mathrm{ARF}}$ transcript corresponding to exon $1 \alpha$ of $\mathrm{p} 16^{\mathrm{INK} 4 \mathrm{~A}}$, followed by missense (16/62) and protein-disrupting (13/62) changes, which are mostly concentrated in exon 2 of p14 ${ }^{\text {ARF }}$. Due to the difference in transcript architecture, there is an overall higher likelihood of encountering variants outside of protein sequence-coding regions (e.g. intronic, 3prime untranslated region) in $\mathrm{p} 14^{\mathrm{ARF}}$ compared to p16 ${ }^{\mathrm{INK} 4 \mathrm{~A}}$.

Based on the distribution of reported neoplasms with germline CDKN2A variants in Table 1 , the association with melanoma is evidently irrespective of variant consequence on both $\mathrm{p} 16^{\mathrm{INK} 4 \mathrm{~A}}$ and $\mathrm{p} 14^{\mathrm{ARF}}$. Variants affecting p16 ${ }^{\mathrm{INK} 4 \mathrm{~A}}$ coding transcript are more frequently observed with pancreatic cancer and HNSCC (23/55) compared to $\mathrm{p} 14^{\mathrm{ARF}}(8 / 29)$. This association is supported by an analysis of Dutch melanoma families demonstrating pancreatic cancer events in $58 \%$ of families with $\mathrm{p} 16^{\mathrm{INK} 4 \mathrm{~A}}$ - affecting variants but none among p14 ${ }^{\mathrm{ARF}}$-affecting carrier families [87]. Intriguingly, a broader spectrum of cancers - e.g. uterine cancer, NSTs, GBM, nonHodgkin's lymphoma - is noted to co-occur with $\mathrm{p} 14^{\mathrm{ARF}}$-affecting variants. Moreover, variants with a lossof-function consequence exclusive to $\mathrm{p} 14^{\mathrm{ARF}}$, namely deletion of exon $1 \beta$, Glu33Glyfs*30 and Arg88*, were observed in individuals with adenocarcinomas of uterus, bladder and stomach, respectively. This apparent distinction of cancers observed with predicted loss either of $\mathrm{p} 16^{\mathrm{INK} 4 \mathrm{~A}}$ or $\mathrm{p} 14^{\mathrm{ARF}}$ function is congruent with the independent roles of both tumor suppressors in regulation of cell cycle progression and p53 pathway. In particular, the range of neoplasms co-occuring with $\mathrm{p} 14^{\mathrm{ARF}}$ variants is reminiscent of Li-Fraumeni syndrome, which is characterized by constitutional mutations in TP53 and diminished p53 activity. Indeed, a dysregulated p53 pathway was observed exclusively in the malignant peripheral nerve sheath tumor (MPNST) of a germline CDKN2A deletion carrier diagnosed with synchronous HNSCC and MPNST [16]. It is also noteworthy that manifestations of neural system-related tumors such as MPNST, GBM, astrocytoma, and schwannoma were consistently reported together with families harbouring gross deletion of the CDKN2A locus and/or involving loss of an intact $\mathrm{p} 14^{\mathrm{ARF}}[12,13,16,62,88]$, suggesting a constitutional deficiency of $\mathrm{p} 14^{\mathrm{ARF}}$ associated with NSTs.

Collectively, these observed trends imply that CDKN2A-associated cancer susceptibility could be dependent on molecular consequence of the variant and affected transcript. While inferring this genotypephenotype relationship is currently limited by the potential bias resulting from a $116^{\mathrm{INK} 4 \mathrm{~A}}$-centric focus in $C D K N 2 A$-related literature, an appreciation for this distinction in $\mathrm{p} 16^{\mathrm{INK} 4 \mathrm{~A}} / \mathrm{p} 14^{\mathrm{ARF}}$ and larger case-cohort studies designed to address the causal effect of the specific variants will provide clarity in the future.

\section{Implications on clinical management}

Presently, clinical genetic testing for $C D K N 2 A$ is indicated for individuals with multiple primary melanoma and/or a family history of melanoma or pancreatic cancer [89]. However, the expanded spectrum of phenotype accompanying germline alterations in $C D K N 2 A$ suggests that it may be relevant to consider $C D K N 2 A$ as a candidate for tumor predisposition beyond melanoma and pancreatic cancer in clinical practice. Indeed, numerous carriers of pathogenic/likely pathogenic variants (P/LPV) listed in Table 1 reported a variable family history of cancers, including sarcoma, leukemia, lymphoma, astrocytoma and cancers of the breast, lung, and prostate. It has been alluded that constitutional deficiency in CDKN2A phenotypically mirrors the broad tumor 


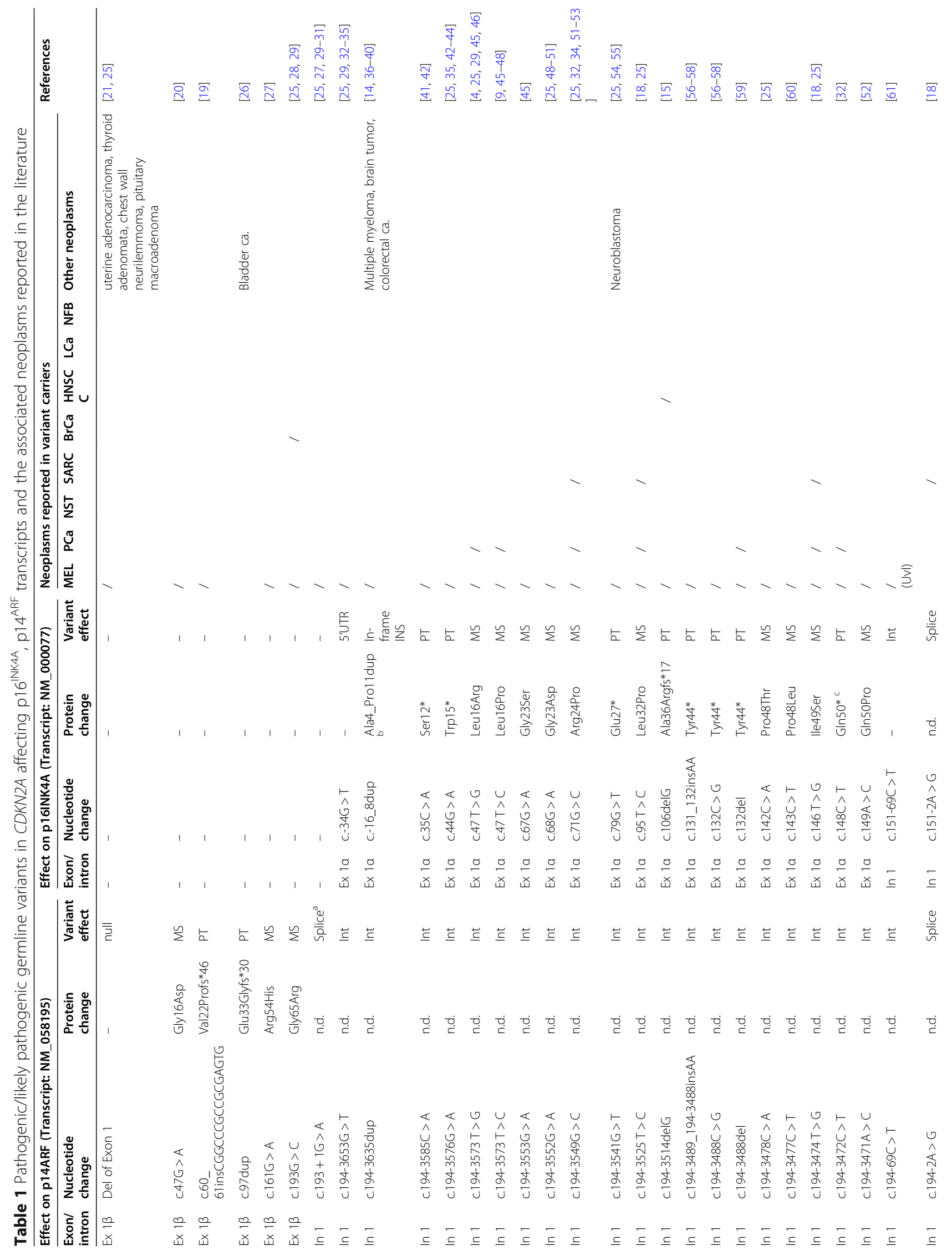




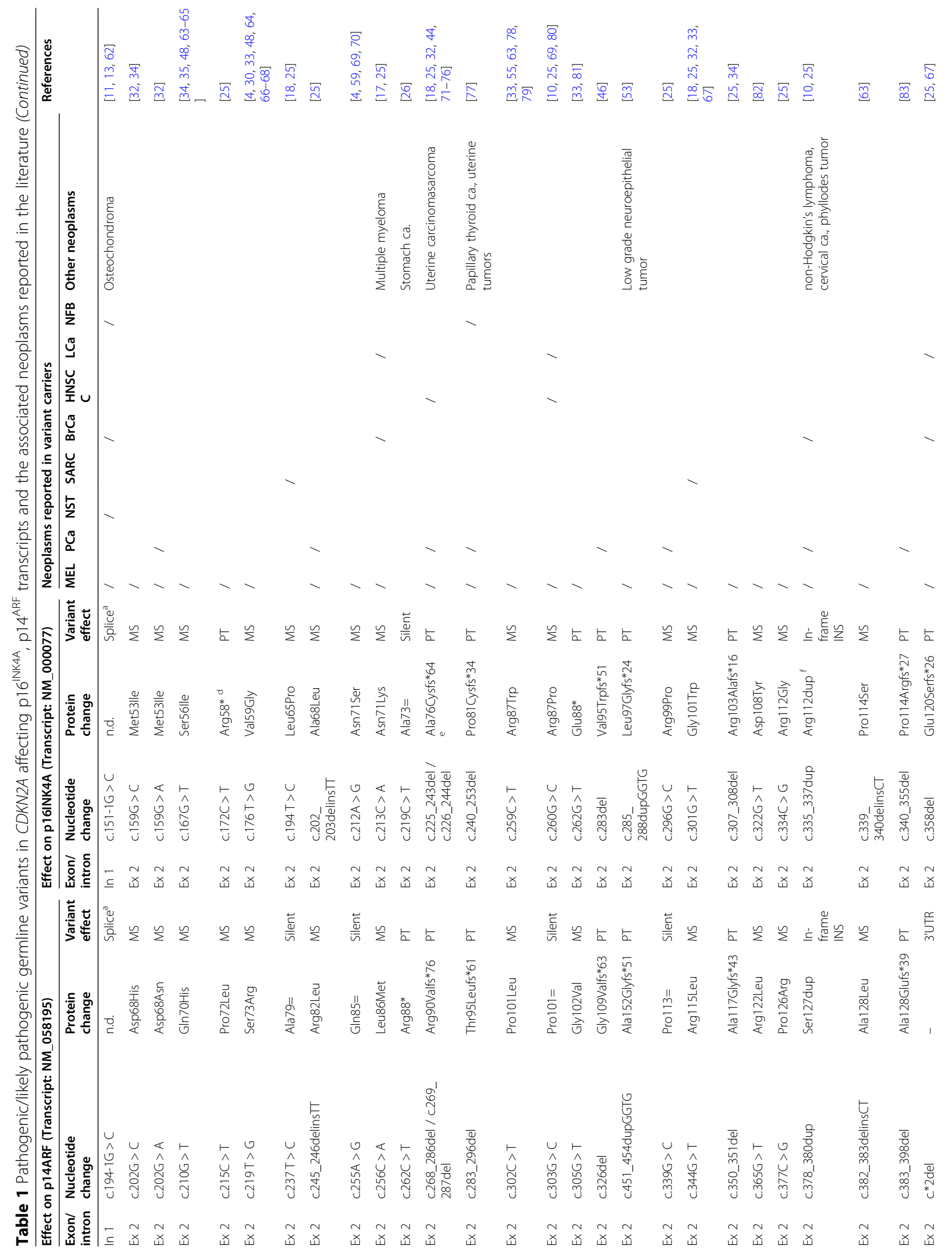




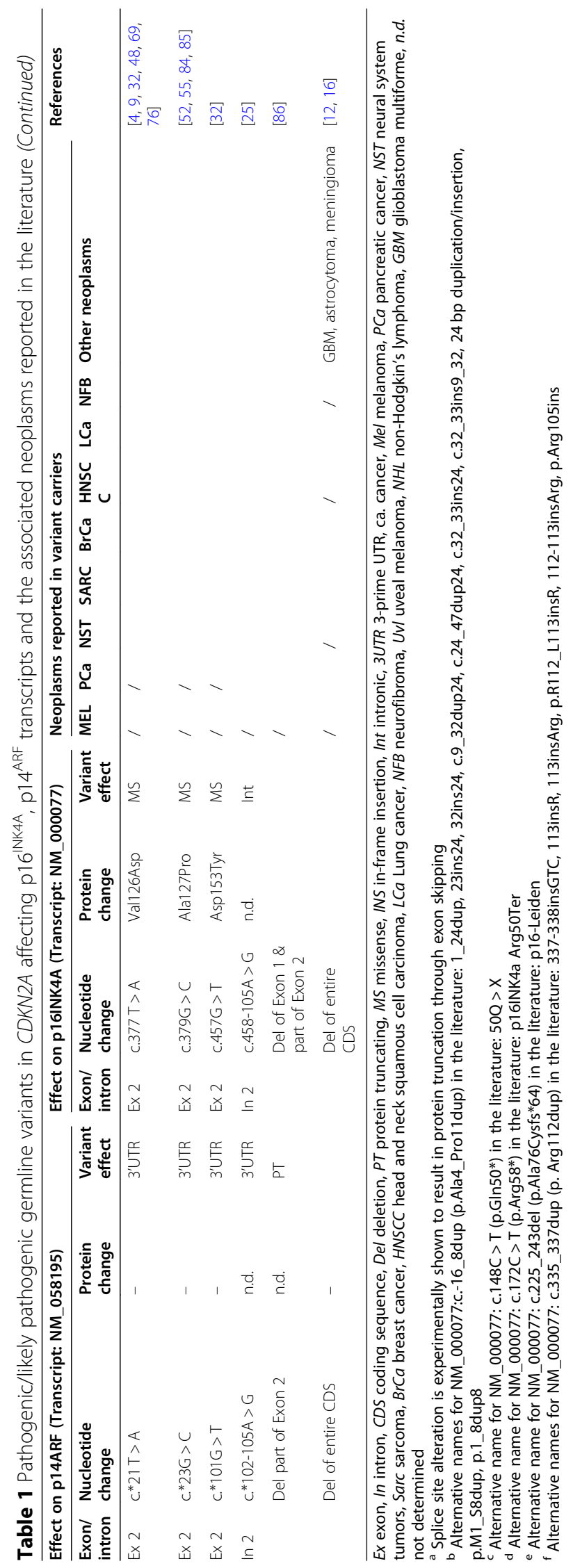


spectrum characteristic of Li-Fraumeni syndrome [13, $16,18,90]$, hence clinicians and genetic professionals should consider $C D K N 2 A$ as a differential diagnosis for cancers such as HNSCC, NSTs, breast cancer, and sarcomas. One potential approach is to evaluate at-risk individuals with an assessment tool built upon a scoring system that accounts for the spectrum of personal and family history of cancers, such as one proposed tailoredapproach for clinical management of hereditary melanoma [91]. Additionally, it is important to be mindful that identification of $C D K N 2 A$ genetic alterations has been historically restricted to the $\mathrm{p} 16^{\mathrm{INK} 4 \mathrm{~A}}$ transcript, which would exclude the alternative coding region specific to p14 ${ }^{\text {ARF }}$ (i.e. exon $1 \beta$ ). This could result in missed diagnoses especially for neoplasms potentially driven by $\mathrm{p} 14^{\mathrm{ARF}}$ deficiency, therefore it is imperative that genetic professionals comprehensively interrogate for alterations in both transcripts.

Current guidelines for clinicians managing individuals tested positive for CDKN2A germline P/LPV are directed towards surveillance for melanoma and pancreatic cancer. Carriers are recommended to undergo bi-annual comprehensive skin examination including scalp and genitalia by a dermatologist, supplemented with total body photography and dermoscopy [92, 93]. Earlier detection of melanoma and non-melanoma skin cancers have been demonstrated among carriers compliant to surveillance [94, 95], although larger cohort studies will be required to better evaluate the outcomes and factors influencing successful melanoma screening. Annual pancreatic surveillance with contrast-enhanced magnetic resonance imaging and/or endoscopic ultrasound is recommended for $C D K N 2 A$ pathogenic variant carriers beginning age 40 years regardless of family history given their high lifetime risk [96] and emerging evidence supporting the potential for downstaging and improved 5year overall survival [97-99]. Patients are also encouraged to adopt lifestyle modifications to reduce cancer risk, including regular exercise, healthy diet, limiting alcohol intake, practicing sun-smart behaviour and smoking cessation. Healthcare professionals caring for CDKN2A carriers should have a heightened index of suspicion for malignancies beyond melanoma and pancreatic cancer. Although there are currently no formal recommendations for surveillance beyond melanoma and pancreatic cancer, clinicians should monitor the presentation of neoplasms within patients' families and consider individualized discussion on the risk and benefit of screening, especially for prevalent cancers. Additionally, at-risk family members should be offered familial genetic testing given that up to $44 \%$ of relatives of index patients carry the familial variant, of whom $96 \%$ were observed to comply with surveillance [100]. Considering the broad range of management strategies, a multidisciplinary approach to care through a centralized cancer genetics service will benefit these patients [101].

With the rapid uptake of multigene panel testing in clinical setting, new data will continuously re-frame our understanding on the genotype-phenotype associations relevant to $C D K N 2 A$. This is exemplified by a recent analysis evaluating the clinical phenotype and molecular results of hereditary cancer predisposition testing in 165, 000 individuals, which revealed an association of germline $C D K N 2 A$ pathogenic variants with increased risk for breast cancer (odds ratio: 3.35, 95\% CI: 1.43-7.75) [102]. Clinicians should keep abreast with the constant updates given that this is an evolving field and that clinical management of individuals harbouring germline CDKN2A variants will likely recalibrate with time.

\section{Conclusion}

Cancer susceptibility among germline variant carriers of $C D K N 2 A$ extend beyond the well-known predisposition to melanoma and pancreatic cancer, potentially associated with a multitude of cancers. The spectrum of associated cancer types may be driven by specific molecular consequences on $\mathrm{p} 16^{\mathrm{INK} 4 \mathrm{~A}}$ and/or $\mathrm{p} 14^{\mathrm{ARF}}$, warranting validation in future studies. Clinicians and genetic professionals should be cognizant of this expanded range of phenotypes and consider $C D K N 2 A$ as a candidate gene for tumor predisposition syndrome in individuals and families presenting with such broad spectrum of cancers.

\section{Abbreviations}

bp: Base pairs; Cl: Confidence interval; GBM: Glioblastoma multiforme; HNSC C: Head and neck squamous cell carcinoma; kb: Kilobase; MPNST: Malignant peripheral nerve sheath tumor; NST: Neural system tumor; P/

LPV: Pathogenic/likely pathogenic variants

\section{Acknowledgements}

Not applicable.

\section{Authors' contributions}

SHC analyzed the data and wrote the manuscript. JBC and JN contributed to writing of the manuscript. All authors read and approved the final manuscript.

\section{Funding}

No separate funding for this review.

\section{Availability of data and materials}

No new data or material. The data used and analysed in this review are derived from ClinVar (https://www.ncbi.nlm.nih.gov/clinvar/) and cited publications.

\section{Declarations}

Ethics approval and consent to participate Not applicable.

Consent for publication Not applicable. 


\section{Competing interests}

$\mathrm{JN}$ receives funding from AstraZeneca for ovarian cancer research. All other authors have no disclosures. All other authors declare that they have no competing interests.

\section{Author details}

${ }^{1}$ Cancer Genetics Service, Division of Medical Oncology, National Cancer Centre Singapore, Singapore 169610, Singapore. ${ }^{2}$ Oncology Academic Clinical Program, Duke-NUS Medical School, Singapore 169857, Singapore. ${ }^{3}$ Lee Kong Chian School of Medicine, Nanyang Technological University Singapore, Singapore 308232, Singapore

Received: 13 November 2020 Accepted: 15 March 2021 Published online: 25 March 2021

\section{References}

1. Zhao R, Choi BY, Lee M-H, Bode AM, Dong Z. Implications of genetic and epigenetic alterations of CDKN2A (p16(INK4a)) in cancer. EBioMedicine. 2016:8:30-9.

2. ICGC/TCGA Pan-Cancer Analysis of Whole Genomes Consortium. Pan-cancer analysis of whole genomes. Nature. 2020;578:82-93.

3. Potrony M, Puig-Butillé JA, Aguilera P, Badenas C, Carrera C, Malvehy J, et al. Increased prevalence of lung, breast, and pancreatic cancers in addition to melanoma risk in families bearing the cyclin-dependent kinase inhibitor 2A mutation: implications for genetic counseling. J Am Acad Dermatol. 2014; 71:888-95.

4. Goldstein AM. Familial melanoma, pancreatic cancer and germline CDKN2A mutations. Hum Mutat. 2004;23:630

5. Goldstein AM, Struewing JP, Fraser MC, Smith MW, Tucker MA. Prospective risk of cancer in CDKN2A germline mutation carriers. J Med Genet. 2004;41: 421-4.

6. Casula M, Paliogiannis P, Ayala F, De Giorgi V, Stanganelli I, Mandalà M, et al. Germline and somatic mutations in patients with multiple primary melanomas: a next generation sequencing study. BMC Cancer. 2019;19:772.

7. Bartsch DK, Sina-Frey M, Lang S, Wild A, Gerdes B, Barth P, et al. CDKN2A germline mutations in familial pancreatic cancer. Ann Surg. 2002;236:730-7.

8. Hu C, Hart SN, Polley EC, Gnanaolivu R, Shimelis H, Lee KY, et al. Association between inherited germline mutations in cancer predisposition genes and risk of pancreatic cancer. JAMA. 2018:319:2401-9.

9. Goldstein AM, Chan M, Harland M, Hayward NK, Demenais F, Bishop DT, et al. Features associated with germline CDKN2A mutations: a GenoMEL study of melanoma-prone families from three continents. J Med Genet. 2007;44:99-106.

10. Borg A, Sandberg T, Nilsson K, Johannsson O, Klinker M, Måsbäck A, et al. High frequency of multiple melanomas and breast and pancreas carcinomas in CDKN2A mutation-positive melanoma families. J Natl Cancer Inst. 2000;92:1260-6.

11. Prowse AH, Schultz DC, Guo S, Vanderveer L, Dangel J, Bove B, et al Identification of a splice acceptor site mutation in p16INK4A/p14ARF within a breast cancer, melanoma, neurofibroma prone kindred. J Med Genet. 2003;40:e102.

12. Bahuau M, Vidaud D, Jenkins RB, Bièche I, Kimmel DW, Assouline B, et al Germ-line deletion involving the INK4 locus in familial proneness to melanoma and nervous system tumors. Cancer Res. 1998;58:2298-303.

13. Sargen MR, Merrill SL, Chu EY, Nathanson KL. CDKN2A mutations with p14 loss predisposing to multiple nerve sheath tumours, melanoma, dysplastic naevi and internal malignancies: a case series and review of the literature. $\mathrm{Br}$ J Dermatol. 2016;175:785-9.

14. Dilworth D, Liu L, Stewart AK, Berenson JR, Lassam N, Hogg D. Germline CDKN2A mutation implicated in predisposition to multiple myeloma. Blood. 2000;95:1869-71

15. Cabanillas R, Astudillo A, Valle M, de la Rosa J, Álvarez R, Durán NS, et al. Novel germline CDKN2A mutation associated with head and neck squamous cell carcinomas and melanomas. Head Neck. 2013;35:E80-4

16. Chan SH, Lim WK, Michalski ST, Lim JQ, Ishak NDB, Met-Domestici M, et al. Germline hemizygous deletion of CDKN2A-CDKN2B locus in a patient presenting with li-Fraumeni syndrome. NPJ Genome Med. 2016;1:16015.

17. Shah V, Boyd KD, Houlston RS, Kaiser MF. Constitutional mutation in CDKN2A is associated with long term survivorship in multiple myeloma: a case report. BMC Cancer. 2017;17:718.
18. Jouenne F, Chauvot de Beauchene I, Bollaert E, Avril M-F, Caron O, Ingster O, et al. Germline CDKN2A/P16INK4A mutations contribute to genetic determinism of sarcoma. J Med Genet. 2017;54:607-12.

19. Rizos H, Darmanian AP, Holland EA, Mann GJ, Kefford RF. Mutations in the INK4a/ARF melanoma susceptibility locus functionally impair p14ARF. J Biol Chem. 2001;276:41424-34.

20. Laud K, Marian C, Avril MF, Barrois M, Chompret A, Goldstein AM, et al. Comprehensive analysis of CDKN2A (p16INK4A/p14ARF) and CDKN2B genes in 53 melanoma index cases considered to be at heightened risk of melanoma. J Med Genet. 2006;43:39-47.

21. Randerson-Moor JA, Harland M, Williams S, Cuthbert-Heavens D, Sheridan E, Aveyard J, et al. A germline deletion of p14(ARF) but not CDKN2A in a melanoma-neural system tumour syndrome family. Hum Mol Genet. 2001; 10:55-62.

22. Yates AD, Achuthan P, Akanni W, Allen J, Allen J, Alvarez-Jarreta J, et al. Ensembl 2020. Nucleic Acids Res. 2020;48:D682-8.

23. Romagosa C, Simonetti S, López-Vicente L, Mazo A, Lleonart ME, Castellvi J, et al. p16 Ink4a overexpression in cancer: a tumor suppressor gene associated with senescence and high-grade tumors. Oncogene Nature Publishing Group. 2011;30:2087-97.

24. Ozenne P, Eymin B, Brambilla E, Gazzeri S. The ARF tumor suppressor: structure, functions and status in cancer. Int J Cancer. 2010;127:2239-47.

25. Goldstein AM, Chan M, Harland M, Gillanders EM, Hayward NK, Avril M-F, et al. High-risk melanoma susceptibility genes and pancreatic cancer, neural system tumors, and uveal melanoma across GenoMEL. Cancer Res. 2006;66: 9818-28.

26. Huang K-L, Mashl RJ, Wu Y, Ritter DI, Wang J, Oh C, et al. Pathogenic germline variants in 10,389 adult cancers. Cell. 2018;173:355-370.e14.

27. Binni F, Antigoni I, De Simone P, Majore S, Silipo V, Crisi A, et al. Novel and recurrent p14 mutations in Italian familial melanoma. Clin Genet. 2010;77: $581-6$.

28. Hewitt C, Lee Wu C, Evans G, Howell A, Elles RG, Jordan R, et al. Germline mutation of ARF in a melanoma kindred. Hum Mol Genet. 2002;11:1273-9.

29. Potjer TP, Helgadottir H, Leenheer M, van der Stoep N, Gruis NA, Höiom V et al. CM-score: a validated scoring system to predict CDKN2A germline mutations in melanoma families from Northern Europe. J Med Genet. 2018. 55:661-8.

30. Pedace L, De Simone $P$, Castori M, Sperduti I, Silipo V, Eibenschutz L, et al. Clinical features predicting identification of CDKN2A mutations in Italian patients with familial cutaneous melanoma. Cancer Epidemiol. 2011;35: e116-20.

31. Harland M, Taylor CF, Chambers PA, Kukalizch K, Randerson-Moor JA, Gruis NA, et al. A mutation hotspot at the p14ARF splice site. Oncogene. 2005;24: 4604-8.

32. Zhen DB, Rabe KG, Gallinger S, Syngal S, Schwartz AG, Goggins MG, et al. BRCA1, BRCA2, PALB2, and CDKN2A mutations in familial pancreatic cancer: a PACGENE study. Genet Med. 2015:17:569-77.

33. Puig S, Potrony M, Cuellar F, Puig-Butille JA, Carrera C, Aguilera P, et al. Characterization of individuals at high risk of developing melanoma in Latin America: bases for genetic counseling in melanoma. Genet Med. 2016;18: 727-36.

34. Monzon J, Liu L, Brill H, Goldstein AM, Tucker MA, From L, et al. CDKN2A mutations in multiple primary melanomas. N Engl J Med. 1998;338:879-87.

35. Bishop DT, Demenais F, Goldstein AM, Bergman W, Bishop JN, Bressac-de Paillerets B, et al. Geographical variation in the penetrance of CDKN2A mutations for melanoma. J Natl Cancer Inst. 2002;94:894-903.

36. Pollock PM, Spurr N, Bishop T, Newton-Bishop J, Gruis N, van der Velden PA, et al. Haplotype analysis of two recurrent CDKN2A mutations in 10 melanoma families: evidence for common founders and independent mutations. Hum Mutat. 1998;11:424-31.

37. Flores JF, Pollock PM, Walker GJ, Glendening JM, Lin AH, Palmer JM, et al. Analysis of the CDKN2A, CDKN2B and CDK4 genes in 48 Australian melanoma kindreds. Oncogene. 1997;15:2999-3005.

38. MacGeoch C, Bishop JA, Bataille V, Bishop DT, Frischauf AM, Meloni R, et al. Genetic heterogeneity in familial malignant melanoma. Hum Mol Genet. 1994:3:2195-200.

39. Walker GJ, Hussussian CJ, Flores JF, Glendening JM, Haluska FG, Dracopoli NC, et al. Mutations of the CDKN2/p16INK4 gene in Australian melanoma kindreds. Hum Mol Genet. 1995:4:1845-52.

40. Pearlman R, Frankel WL, Swanson B, Zhao W, Yilmaz A, Miller K, et al. Prevalence and spectrum of germline cancer susceptibility gene mutations 
among patients with early-onset colorectal cancer. JAMA Oncol. 2017;3:46471.

41. Casula M, Colombino M, Satta MP, Cossu A, Lissia A, Budroni M, et al. Factors predicting the occurrence of germline mutations in candidate genes among patients with cutaneous malignant melanoma from South Italy. Eur J Cancer. 2007:43:137-43.

42. Taylor NJ, Mitra N, Goldstein AM, Tucker MA, Avril M-F, Azizi E, et al. Germline variation at CDKN2A and associations with nevus phenotypes among members of melanoma families. J Invest Dermatol. 2017;137:260612.

43. FitzGerald MG, Harkin DP, Silva-Arrieta S, MacDonald DJ, Lucchina LC, Unsal $\mathrm{H}$, et al. Prevalence of germ-line mutations in p16, p19ARF, and CDK4 in familial melanoma: analysis of a clinic-based population. Proc Natl Acad Sci U S A. 1996;93:8541-5.

44. Yurgelun MB, Chittenden AB, Morales-Oyarvide V, Rubinson DA, Dunne RF, Kozak MM, et al. Germline cancer susceptibility gene variants, somatic second hits, and survival outcomes in patients with resected pancreatic cancer. Genet Med. 2019;21:213-23.

45. Orlow I, Begg CB, Cotignola J, Roy P, Hummer AJ, Clas BA, et al. CDKN2A germline mutations in individuals with cutaneous malignant melanoma. J Invest Dermatol. 2007;127:1234-43.

46. McWilliams RR, Wieben ED, Rabe KG, Pedersen KS, Wu Y, Sicotte $H$, et al. Prevalence of CDKN2A mutations in pancreatic cancer patients: implications for genetic counseling. Eur J Hum Genet. 2011;19:472-8.

47. Monnerat C, Chompret A, Kannengiesser C, Avril M-F, Janin N, Spatz A, et al. BRCA1, BRCA2, TP53, and CDKN2A germline mutations in patients with breast cancer and cutaneous melanoma. Familial Cancer. 2007;6:453-61.

48. Soufir N, Avril MF, Chompret A, Demenais F, Bombled J, Spatz A, et al. Prevalence of p16 and CDK4 germline mutations in 48 melanoma-prone families in France. The French Familial Melanoma Study Group. Hum Mol Genet. 1998;7:209-16.

49. Hocevar M, Avbelj M, Perić B, Zgajnar J, Besić N, Battelino T. High prevalence of germline CDKN2A mutations in Slovenian cutaneous malignant melanoma families. Croat Med J. 2006;47:851-4.

50. Harland M, Cust AE, Badenas C, Chang Y-M, Holland EA, Aguilera P, et al. Prevalence and predictors of germline CDKN2A mutations for melanoma cases from Australia, Spain and the United Kingdom. Hered Cancer Clin Pract. 2014;12:20.

51. Fargnoli MC, Chimenti S, Keller G, Soyer HP, Dal Pozzo V, Höfler H, et al. CDKN2a/p16INK4a mutations and lack of p19ARF involvement in familial melanoma kindreds. J Invest Dermatol. 1998;111:1202-6.

52. Lynch HT, Brand RE, Hogg D, Deters CA, Fusaro RM, Lynch JF, et al. Phenotypic variation in eight extended CDKN2A germline mutation familial atypical multiple mole melanoma-pancreatic carcinoma-prone families: the familial atypical mole melanoma-pancreatic carcinoma syndrome. Cancer. 2002;94:84-96.

53. Fiala EM, Jayakumaran G, Mauguen A, et al. Prospective pan-cancer germline testing using MSK-IMPACT informs clinical translation in 751 patients with pediatric solid tumors. Nat Cancer. 2021. https://doi.org/10.103 8/s43018-021-00172-1.

54. Ghiorzo P, Gargiulo S, Pastorino L, Nasti S, Cusano R, Bruno W, et al. Impact of E27X, a novel CDKN2A germ line mutation, on p16 and p14ARF expression in Italian melanoma families displaying pancreatic cancer and neuroblastoma. Hum Mol Genet. 2006;15:2682-9.

55. Helsing P, Nymoen DA, Ariansen S, Steine SJ, Maehle L, Aamdal S, et al. Population-based prevalence of CDKN2A and CDK4 mutations in patients with multiple primary melanomas. Genes Chromosomes Cancer. 2008;47: 175-84.

56. de Snoo FA, Kroon MW, Bergman W, ter Huurne JAC, Houwing-Duistermaat $J$ J, van Mourik L, et al. From sporadic atypical nevi to familial melanoma: risk analysis for melanoma in sporadic atypical nevus patients. J Am Acad Dermatol. 2007:56:748-52.

57. Begg CB, Orlow I, Hummer AJ, Armstrong BK, Kricker A, Marrett LD, et al. Lifetime risk of melanoma in CDKN2A mutation carriers in a populationbased sample. J Natl Cancer Inst. 2005;97:1507-15.

58. MacKie RM, Andrew N, Lanyon WG, Connor JM. CDKN2A germline mutations in U.K. patients with familial melanoma and multiple primary melanomas. J Invest Dermatol. 1998;111:269-72.

59. Majore S, De Simone P, Crisi A, Eibenschutz L, Binni F, Antigoni I, et al. CDKN2A/CDK4 molecular study on 155 Italian subjects with familial and/or primary multiple melanoma. Pigment Cell Melanoma Res. 2008;21:209-11.
60. Platz A, Hansson J, Månsson-Brahme E, Lagerlöf B, Linder S, Ringborg U, et al. Screening of germline mutations in the CDKN2A and CDKN2B genes in Swedish families with hereditary cutaneous melanoma. J Natl Cancer Inst Oxford Academic. 1997:89:697-702.

61. Abdel-Rahman MH, Pilarski R, Massengill JB, Christopher BN, Noss R, Davidorf FH. Melanoma candidate genes CDKN2A/p16/INK4A, p14ARF, and CDK4 sequencing in patients with uveal melanoma with relative high-risk for hereditary cancer predisposition. Melanoma Res. 2011;21:175-9.

62. Petronzelli F, Sollima D, Coppola G, Martini-Neri ME, Neri G, Genuardi M. CDKN2A germline splicing mutation affecting both p16(ink4) and p14(arf) RNA processing in a melanoma/neurofibroma kindred. Genes Chromosomes Cancer. 2001;31:398-401.

63. Kannengiesser C, Dalle S, Leccia M-T, Avril MF, Bonadona V, Chompret A, et al. New founder germline mutations of CDKN2A in melanoma-prone families and multiple primary melanoma development in a patient receiving levodopa treatment. Genes Chromosomes Cancer. 2007;46:75160.

64. Maubec E, Chaudru V, Mohamdi H, Blondel C, Margaritte-Jeannin P, Forget $S$, et al. Familial melanoma: clinical factors associated with germline CDKN2A mutations according to the number of patients affected by melanoma in a family. J Am Acad Dermatol. 2012;67:1257-64.

65. Landi MT, Goldstein AM, Tsang S, Munroe D, Modi W, Ter-Minassian M, et al. Genetic susceptibility in familial melanoma from northeastern Italy. J Med Genet. 2004:41:557-66

66. Yakobson E, Eisenberg S, Isacson R, Halle D, Levy-Lahad E, Catane R, et al. A single Mediterranean, possibly Jewish, origin for the Val59Gly CDKN2A mutation in four melanoma-prone families. Eur J Hum Genet. 2003;11:28896.

67. de Torre C, Martínez-Escribano J. Novel CDKN2A mutation detected in Spanish melanoma pedigree. Exp Dermatol. 2010;19:e333-5.

68. Nagore E, Montoro A, García-Casado Z, Botella-Estrada R, Insa A, Lluch A, et al. Germline mutations in CDKN2A are infrequent in female patients with melanoma and breast cancer. Melanoma Res. 2009;19:211-4.

69. Hussussian CJ, Struewing JP, Goldstein AM, Higgins PA, Ally DS, Sheahan MD, et al. Germline p16 mutations in familial melanoma. Nat Genet. 1994;8: $15-21$.

70. Newton Bishop JA, Harland M, Bennett DC, Bataille V, Goldstein AM, Tucker MA, et al. Mutation testing in melanoma families: INK4A, CDK4 and INK4D. Br J Cancer. 1999;80:295-300.

71. Gruis NA, van der Velden PA, Sandkuijl LA, Prins DE, Weaver-Feldhaus J, Kamb A, et al. Homozygotes for CDKN2 (p16) germline mutation in Dutch familial melanoma kindreds. Nat Genet. 1995;10:351-3.

72. van der Velden PA, Sandkuijl LA, Bergman W, Hille ET, Frants RR, Gruis NA. A locus linked to p16 modifies melanoma risk in Dutch familial atypical multiple mole melanoma (FAMMM) syndrome families. Genome Res. 1999;9: 575-80

73. Vasen HF, Gruis NA, Frants RR, van Der Velden PA, Hille ET, Bergman W. Risk of developing pancreatic cancer in families with familial atypical multiple mole melanoma associated with a specific 19 deletion of p16 (p16-Leiden). Int J Cancer. 2000;87:809-11.

74. Schneider-Stock R, Giers A, Motsch C, Boltze C, Evert M, Freigang B, et al. Hereditary p16-Leiden mutation in a patient with multiple head and neck tumors. Am J Hum Genet. 2003;72:216-8.

75. Harinck F, Kluijt I, van der Stoep N, Oldenburg RA, Wagner A, Aalfs CM, et al. Indication for CDKN2A-mutation analysis in familial pancreatic cancer families without melanomas. J Med Genet. 2012;49:362-5.

76. Cremin C, Lee MK-C, Hong Q, Hoeschen C, Mackenzie A, Dixon K, et al. Burden of hereditary cancer susceptibility in unselected patients with pancreatic ductal adenocarcinoma referred for germline screening. Cancer Med. 2020;9:4004-13.

77. Vanneste R, Smith E, Graham G. Multiple neurofibromas as the presenting feature of familial atypical multiple malignant melanoma (FAMMM) syndrome. Am J Med Genet A. 2013;161A:1425-31.

78. Ruiz A, Puig S, Malvehy J, Lázaro C, Lynch M, Gimenez-Arnau AM, et al. CDKN2A mutations in Spanish cutaneous malignant melanoma families and patients with multiple melanomas and other neoplasia. J Med Genet. 1999; 36:490-3.

79. Karagianni F, Njauw C-N, Kypreou KP, Stergiopoulou A, Plaka M, Polydorou D, et al. CDKN2A/CDK4 status in Greek patients with familial melanoma and association with clinico-epidemiological parameters. Acta Derm Venereol. 2018;98:862-6. 
80. Yu KK, Zanation AM, Moss JR, Yarbrough WG. Familial head and neck cancer: molecular analysis of a new clinical entity. Laryngoscope. 2002;112: 1587-93.

81. Larre Borges A, Borges AL, Cuéllar F, Puig-Butillé JA, Scarone M, Delgado L, et al. CDKN2A mutations in melanoma families from Uruguay. $\mathrm{Br} J$ Dermatol. 2009;161:536-41.

82. Erlandson A, Appelqvist F, Wennberg A-M, Holm J, Enerbäck C. Novel CDKN2A mutations detected in western Swedish families with hereditary malignant melanoma. J Invest Dermatol. 2007;127:1465-7.

83. Lowery MA, Wong W, Jordan EJ, Lee JW, Kemel Y, Vijai J, et al. Prospective evaluation of germline alterations in patients with exocrine pancreatic neoplasms. J Natl Cancer Inst. 2018;110:1067-74.

84. Pastorino L, Bonelli L, Ghiorzo P, Queirolo P, Battistuzzi L, Balleari E, et al. CDKN2A mutations and MC1R variants in Italian patients with single or multiple primary melanoma. Pigment Cell Melanoma Res. 2008;21:700-9.

85. Ghiorzo P, Fornarini G, Sciallero S, Battistuzzi L, Belli F, Bernard L, et al. CDKN2A is the main susceptibility gene in Italian pancreatic cancer families. J Med Genet. 2012:49:164-70

86. Knappskog S, Geisler J, Arnesen T, Lillehaug JR, Lønning PE. A novel type of deletion in the CDKN2A gene identified in a melanoma-prone family. Genes Chromosomes Cancer. 2006;45:1155-63.

87. Overbeek KA, Rodríguez-Girondo MD, Wagner A, van der Stoep N, van den Akker PC, Oosterwijk JC, et al. Genotype-phenotype correlations for pancreatic cancer risk in Dutch melanoma families with pathogenic CDKN2A variants. J Med Genet. 2020. https://doi.org/10.1136/jmedgenet-2 019-106562.

88. Pasmant $\mathrm{E}$, Laurendeau I, Héron D, Vidaud M, Vidaud D, Bièche I. Characterization of a germ-line deletion, including the entire INK4/ARF locus, in a melanoma-neural system tumor family: identification of ANRIL, an antisense noncoding RNA whose expression coclusters with ARF. Cancer Res. 2007:67:3963-9.

89. Leachman SA, Carucci J, Kohlmann W, Banks KC, Asgari MM, Bergman W, et al. Selection criteria for genetic assessment of patients with familial melanoma. J Am Acad Dermatol. 2009;61:677.e1-14.

90. Zhang $Y$, Xiong Y. Mutations in human ARF exon 2 disrupt its nucleolar localization and impair its ability to block nuclear export of MDM2 and p53. Mol Cell. 1999:3:579-91.

91. Leachman SA, Lucero OM, Sampson JE, Cassidy P, Bruno W, Queirolo P, et al. Identification, genetic testing, and management of hereditary melanoma. Cancer Metastasis Rev. 2017;36:77-90.

92. Katalinic A, Waldmann A, Weinstock MA, Geller AC, Eisemann N, Greinert R, et al. Does skin cancer screening save lives?: an observational study comparing trends in melanoma mortality in regions with and without screening. Cancer. 2012;118:5395-402.

93. Halpern AC, Marchetti MA, Marghoob AA. Melanoma surveillance in "highrisk" individuals. JAMA Dermatol. 2014:150:815-6.

94. van der Rhee Jl, de Snoo FA, Vasen HFA, Mooi WJ, Putter H, Gruis NA, et al. Effectiveness and causes for failure of surveillance of CDKN2A-mutated melanoma families. J Am Acad Dermatol. 2011;65:289-96

95. Moloney FJ, Guitera P, Coates E, Haass NK, Ho K, Khoury R, et al. Detection of primary melanoma in individuals at extreme high risk: a prospective 5year follow-up study. JAMA Dermatol. 2014;150:819-27.

96. Goggins M, Overbeek KA, Brand R, Syngal S, Del Chiaro M, Bartsch DK, et al. Management of patients with increased risk for familial pancreatic cancer: updated recommendations from the international Cancer of the pancreas screening (CAPS) consortium. Gut. 2020;69:7-17.

97. Vasen H, Ibrahim I, Ponce CG, Slater EP, Matthäi E, Carrato A, et al. Benefit of surveillance for pancreatic cancer in high-risk individuals: outcome of longterm prospective follow-up studies from three European expert centers. J Clin Oncol. 2016:34:2010-9.

98. Paiella S, Capurso G, Cavestro GM, Butturini G, Pezzilli R, Salvia R, et al. Results of first-round of surveillance in individuals at high-risk of pancreatic cancer from the AISP (Italian Association for the Study of the Pancreas) Registry. Am J Gastroenterol. 2019;114:665-70.

99. Canto MI, Almario JA, Schulick RD, Yeo CJ, Klein A, Blackford A, et al. Risk of neoplastic progression in individuals at high risk for pancreatic cancer undergoing long-term surveillance. Gastroenterology. 2018;155:740-751.e2.

100. Levin T, Mæhle L. Uptake of genetic counseling, genetic testing and surveillance in hereditary malignant melanoma (CDKN2A) in Norway. Familial Cancer. 2017;16:257-65.
101. Chiang J, Ngeow J. The management of BRCA1 and BRCA2 carriers in Singapore. Chin Clin Oncol. 2020;9(5):62.

102. LaDuca H, Polley EC, Yussuf A, Hoang L, Gutierrez S, Hart SN, et al. A clinical guide to hereditary cancer panel testing: evaluation of gene-specific cancer associations and sensitivity of genetic testing criteria in a cohort of 165,000 high-risk patients. Genet Med. 2020;22:407-15.

\section{Publisher's Note}

Springer Nature remains neutral with regard to jurisdictional claims in published maps and institutional affiliations.
Ready to submit your research? Choose BMC and benefit from:

- fast, convenient online submission

- thorough peer review by experienced researchers in your field

- rapid publication on acceptance

- support for research data, including large and complex data types

- gold Open Access which fosters wider collaboration and increased citations

- maximum visibility for your research: over $100 \mathrm{M}$ website views per year

At BMC, research is always in progress.

Learn more biomedcentral.com/submissions 